University of Nebraska - Lincoln

DigitalCommons@University of Nebraska - Lincoln

Papers in the Earth and Atmospheric Sciences Earth and Atmospheric Sciences, Department

2009

\title{
Biostratigraphy of the Hunter Creek Sandstone, Verdi Basin, Washoe County, Nevada
}

Thomas S. Kelly

Natural History Museum of Los Angeles County, tom@tskelly.gardnerville.nv.us

Ross Secord

University of Nebraska-Lincoln, rsecord2@unl.edu

Follow this and additional works at: https://digitalcommons.unl.edu/geosciencefacpub

Part of the Earth Sciences Commons

Kelly, Thomas S. and Secord, Ross, "Biostratigraphy of the Hunter Creek Sandstone, Verdi Basin, Washoe County, Nevada" (2009). Papers in the Earth and Atmospheric Sciences. 200.

https://digitalcommons.unl.edu/geosciencefacpub/200

This Article is brought to you for free and open access by the Earth and Atmospheric Sciences, Department of at DigitalCommons@University of Nebraska - Lincoln. It has been accepted for inclusion in Papers in the Earth and Atmospheric Sciences by an authorized administrator of DigitalCommons@University of Nebraska - Lincoln. 


\title{
Biostratigraphy of the Hunter Creek Sandstone, Verdi Basin, Washoe County, Nevada
}

\author{
Thomas S. Kelly* \\ Vertebrate Paleontology Section, Natural History Museum of Los Angeles County, 900 Exposition Blvd., \\ Los Angeles, California 90007, USA \\ Ross Secord \\ Department of Geosciences and Nebraska State Museum, University of Nebraska, 200 Bessey Hall, Lincoln, Nebraska 68588, USA
}

\begin{abstract}
The Hunter Creek Sandstone of the Verdi Basin, Nevada, yielded a succession of superposed continental faunal assemblages ranging in age from the late Clarendonian (late Miocene) through the late Blancan (late Pliocene) in the North American land mammal age framework, or ca. 10.5-2.5 Ma. We describe two new local faunas from the Hunter Creek Sandstone: the East Verdi local fauna, of late-medial to late Clarendonian age, which includes Dinohippus cf. D. leardi, Camelidae, ?Antilocapridae, and Mammutidae or Gomphotheriidae; and the Mogul local fauna, of Hemphillian age, which includes Dinohippus sp., Rhinocerotidae, Camelidae (at least two species), Mam$m u t$ sp., and possibly Gomphotheriidae. A third unnamed assemblage, of latest Hemphillian or earliest Blancan age, is represented by a small sample of fossils from W.M. Keck Museum locality P-105. The only taxa recovered from this locality are cf. Megatylopus and Gomphotheriidae or Mammutidae. A single late Blancan locality, the Byland locality, yielded Equus idahoensis. The recognition of this faunal succession provides a biostratigraphic framework for the Hunter Creek Sandstone that corroborates and is consistent with the previous chronostratigraphy based on radioisotopic and tephrochronologic dating methods.
\end{abstract}

Keywords: Clarendonian, Hemphillian, Blancan, biostratigraphy, Nevada.

\section{INTRODUCTION}

The Verdi Basin is a structural basin that extends along the valley of the Truckee River and surrounding foothills from the west side of the community of Reno, Nevada, to the vicinity of Boca Reservoir, California (Trexler et al., 2000). Neogene sedimentary rocks are well exposed within the Verdi Basin (Fig. 1). These sedimentary rocks were originally mapped by King (1878) as Truckee Formation, the type section of which occurs $\sim 90 \mathrm{~km}$ to the northeast in Churchill County, Nevada. Axelrod $(1956,1958)$ reevaluated this sedimentary unit and referred it instead to the Coal Valley Formation, the type section of which occurs $\sim 120 \mathrm{~km}$ to the southeast in Coal Valley, Lyon County, Nevada. Bingler (1975) described the Verdi Basin sedimentary rocks and informally referred to them as the "Sandstone of the Hunter Creek." More recent investigators have recognized that these rocks were depos-

\footnotetext{
*Corresponding author e-mail: tom@tskelly.gardnerville.nv.us.

Kelly, T.S., and Secord, R., 2009, Biostratigraphy of the Hunter Creek Sandstone, Verdi Basin, Washoe County, Nevada, in Oldow, J.S., and Cashman, P.H., eds., Late Cenozoic Structure and Evolution of the Great Basin-Sierra Nevada Transition: Geological Society of America Special Paper 447, p. 133-146, doi: 10.1130/2009.2447(08). For permission to copy, contact editing@geosociety.org. @2009 The Geological Society of America. All rights reserved.
} 


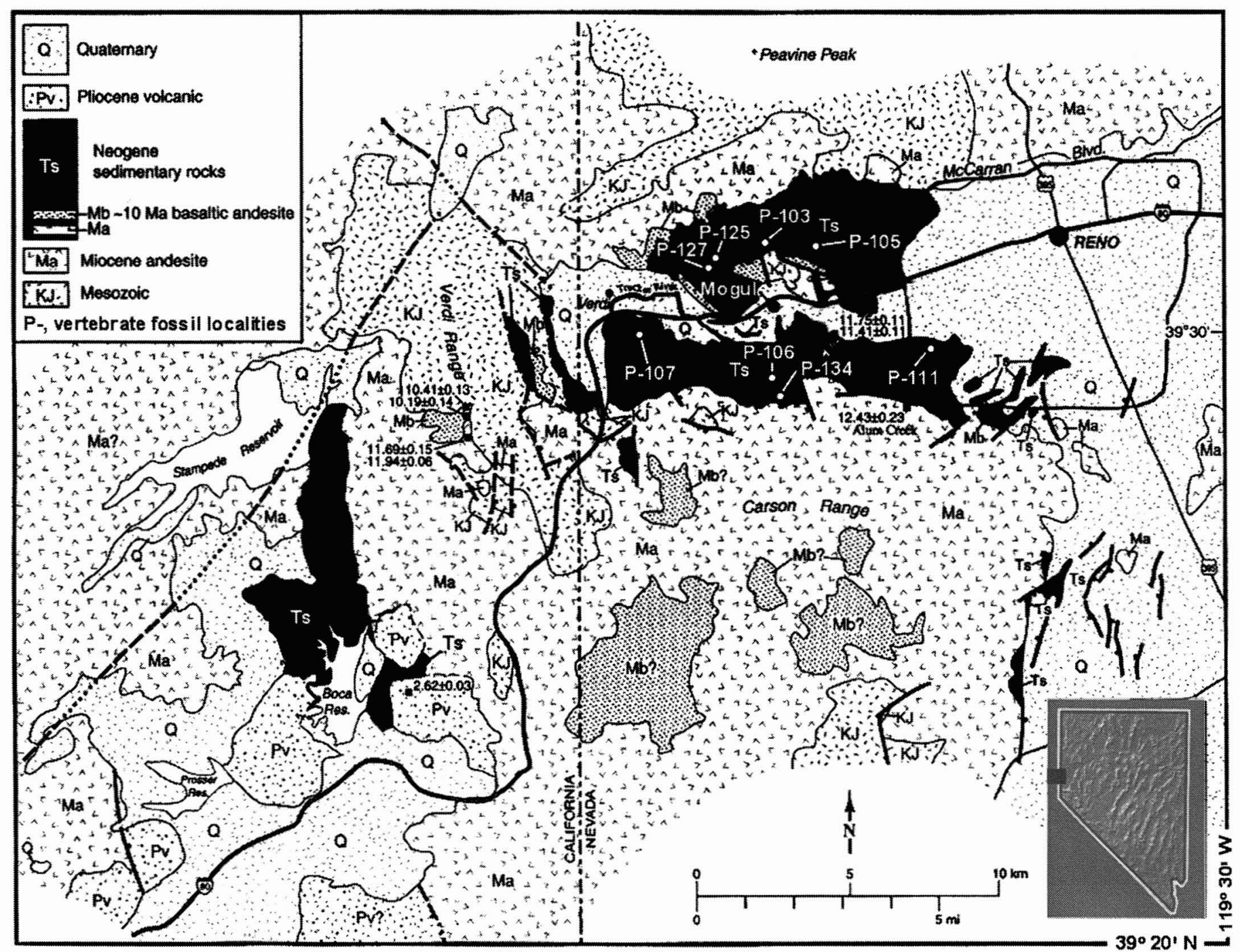

Figure 1. Geologic map of the Verdi Basin showing distribution of Neogene sedimentary rocks and geographic locations of selected W.M. Keck museum vertebrate fossil localities (P-) representing different stratigraphic levels within the Hunter Creek Sandstone (map modified from Trexler et al., 2000). Nevada map insert shows geographic location of Verdi Basin.

ited within a separate depositional basin from those of the type Truckee and Coal Valley Formations and should not be referred to either of these units (e.g., Kelly, 1998a; Trexler et al., 2000). Trexler et al. (2000) demonstrated that the Neogene sedimentary rocks of the Verdi Basin represent a continuously deposited rock unit that should be regarded as a distinct formation. For the purpose of this report, the informal name Hunter Creek Sandstone will be used for the Neogene sedimentary rocks of the Verdi Basin.

The Hunter Creek Sandstone is composed of fluvial, delta and fan-delta, and lacustrine deposits, with minor debris-flow lahars at several stratigraphic levels within the formation (Trexler et al., 2000). Trexler et al. (2000) recognized four facies within the Hunter Creek Sandstone: (1) fluvial facies consisting of conglomerate, sandstone, and intercalated mudstone; (2) deltaic facies consisting of minor conglomerate, coarse- to fine-grained sandstone, and mudstone; (3) lacustrine facies consisting of diatomite and silty diatomite; and (4) lahar deposits consisting of distinctive coarse-grained breccia. Whole-rock and single-crystal (plagioclase and hornblende) ${ }^{40} \mathrm{Ar} /{ }^{39} \mathrm{Ar}$ radioisotopic dating, tephrochronologic dating of volcanic tuffs, and biostratigraphic data indicate that the Hunter Creek Sandstone was deposited from ca. 11 to $2.5 \mathrm{Ma}$ (Garside et al., 2000; Trexler et al., 2000).

Ninety-five years ago, Buwalda (1914) described the first fossil mammal from the Hunter Creek Sandstone, a partial mastodon tooth from the Verdi area. Axelrod (1958) stated that this tooth was found $\sim 1.2 \mathrm{~km}(\sim 0.75$ mile) southeast of the community of Verdi, but the exact location was unknown. Subsequently, two additional fragmentary mammalian fossils from the Hunter Creek Sandstone were reported in the literature. Axelrod (1958) noted that a second mastodon tooth was discovered from 
exposures near the community of Mogul, and a partial horse tooth, which he regarded as representing either Hipparion or Neohipparion, was discovered $\sim 1.6 \mathrm{~km}(\sim 1$ mile) north of Mogul. Axelrod (1958) also described a diverse flora from University of California plant locality 102 (the Verdi Flora), which occurs in a railroad cut along the Southern Pacific Railroad near the Truckee River, just west of Mogul. The Verdi Flora is regarded as Hemphillian (late Miocene) in age based on paleobotanical correlation and a K-Ar radioisotopic age of 5.85 Ma (recalculated; see Methods) from the locality (Axelrod, 1958; Evernden and James, 1964; Schorn et al., 1994). During this study, we relocated and surface prospected the two known vertebrate fossil localities within the Hunter Creek Sandstone and discovered many new localities. The most productive localities occur on private lands to the north of the Truckee River and the community of Mogul. Additional localities were discovered south of the Truckee River and within the Toiyabe National Forest. The purposes of this report are to: (1) document the new fossil localities; (2) identify and describe the new fossil specimens; and (3) construct a biostratigraphic framework for the Hunter Creek Sandstone. The biostratigraphic framework provides independent age constraints for the Hunter Creek Sandstone, and it will be used to test the existing chronostratigraphy, which is based on radioisotopic and tephrochronologic methods, for congruence.

\section{METHODS}

The two previously known fossil localities were relocated using published records and locality data on file at the W.M. Keck Museum. Exposures of the Hunter Creek Sandstone were examined and surface prospected for additional vertebrate fossil localities. All specimens discovered during this study were deposited in the W.M. Keck Museum, Mackay School of Mines, University of Nevada, Reno. Specimens collected within the Toiyabe National Forest were collected under the U.S. Department of Agriculture Forest Service Special Use Permit CAR37. All locality data are on file at W.M. Keck Museum, University of Nevada, Reno.

Trexler et al. (2000) recently provided a summary of the geology and stratigraphy of the Hunter Creek Sandstone of the Verdi Basin. They provided whole-rock and single-crystal ${ }^{40} \mathrm{Ar}{ }^{\beta 9} \mathrm{Ar}$ (hornblende and plagioclase) radioisotopic ages from three different stratigraphic levels in the basin. Plagioclase from the "Kate Peak"-type andesitic lavas that directly underlie the Hunter Creek Sandstone at Alum Creek yielded a ${ }^{40} \mathrm{Ar}{ }^{39} \mathrm{Ar}$ age of $12.43 \pm 0.23 \mathrm{Ma}$ (plagioclase), and similar andesite capping in the Verdi Range yielded ages of $11.69 \pm 0.15 \mathrm{Ma}$ (plagioclase) and $11.94 \pm 0.06 \mathrm{Ma}$ (hornblende). Clasts from an andesite breccia, which were shown to be contemporaneous with additional "Kate Peak"-type volcanism at the base of the Hunter Creek Sandstone (Trexler et al., 2000), provided ${ }^{40} \mathrm{Ar}{ }^{\beta 9} \mathrm{Ar}$ ages of $11.41 \pm 0.11 \mathrm{Ma}$ (plagioclase) and $11.75 \pm 0.10 \mathrm{Ma}$ (hornblende). A group of mafic lavas, which lie within the lower part of the Hunter Creek Sandstone in many areas of the Verdi Basin, provided five ${ }^{40} \mathrm{Ar}{ }^{39} \mathrm{Ar}$ (whole-rock) ages within a narrow range of $10.19 \pm 0.14 \mathrm{Ma}$ to $10.41 \pm 0.13 \mathrm{Ma}$. In addition, they identified several ash beds within the thick lacustrine facies of the upper half of the formation that were correlated geochemically with known, regional tephras dated at $3.0-3.1$ and $4.4-4.8 \mathrm{Ma}$ $( \pm 2 \sigma$, not provided). Their work helped to provide a basis for correlating the stratigraphic positions of the fossil localities within the Verdi Basin.

Measurements of teeth and appendicular elements were made to the nearest $0.1 \mathrm{~mm}$ with a Vernier caliper. All horse specimens were measured following the standards set forth by Eisenmann et al. (1988), and horse dental terminology follows MacFadden (1984). Definitions of the wear stages for horse cheek teeth follow Kelly (1998b). All other specimens were measured at their greatest dimensions. Upper teeth are designated by uppercase letters, and lower teeth are designated by lowercase letters. Metric abbreviations and dental formulae follow standard usage. Definition of taxon-range chron (= range chron of Walsh, 1998) follows Woodburne (2004), and definition of chronostratigraphy follows Aubry et al. (1999). Subzones or subages (e.g., Cl2, Cl3, Hh1, Hh2, Hh3) of the Clarendonian and Hemphillian North American land mammal ages follow Tedford et al. (2004), and Blancan $\mathrm{V}$ arvicoline division of the Blancan land mammal age follows Repenning (1987) and Bell et al. (2004). All taxonomic identifications were determined by the authors using published accounts and comparative material in the vertebrate paleontology collections of the Natural History Museum of Los Angeles County, the Museum of Paleontology, University of California, and the W.M. Keck Museum, University of Nevada, Reno.

Older published K-Ar radioisotopic ages presented herein were recalibrated using International Union of Geological Sciences constants following the method of Dalrymple (1979). Older published ${ }^{40} \mathrm{Ar} /{ }^{\beta 9} \mathrm{Ar}$ ages were recalibrated relative to the Fish Canyon Tuff sanidine interlaboratory standard at $28.02 \mathrm{Ma}$. All radioisotopic ages include $\pm 2 \sigma$ (deviation), except those that were published without any citation for their deviations.

Abbreviations and institutional acronyms are as follows: A-P—anteroposterior; L- left; lf — local fauna; LACM-Natural History Museum of Los Angeles County; Ma-million yr B.P.; $\mathrm{R}$-right; ROC - radius of curvature; TR-transverse; UCMPMuseum of Paleontology, University of California, Berkeley; WMK-W.M. Keck Museum, Mackay School of Mines, University of Nevada, Reno; WMK P-vertebrate fossil locality.

\section{SYSTEMATIC PALEONTOLOGY}

Class Mammalia Linnaeus, 1758

Order Perissodactyla Owen, 1848

Family Rhinocerotidae Owen, 1845

Rhinocerotidae, genus and species indeterminate

Referred specimens: From locality WMK P-103: partial lower premolar, WMK 6623. From locality WMK P-126: cheek tooth fragment, WMK 6718. From locality WMK P-104: cheek tooth fragment, WMK 6635.

Age and fauna: Hemphillian, Mogul lf. 


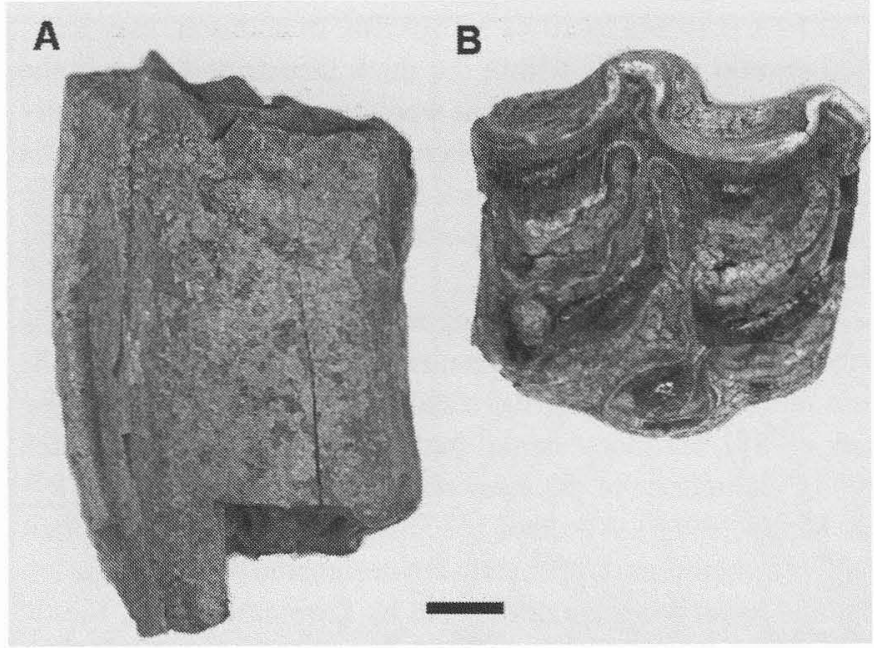

Figure 2. Dinohippus cf. D. leardi from East Verdi lf. (A) RP4, WMK 6712 , posterior view. (B) RP4, WMK 6712, occlusal view. Bar scale $=5 \mathrm{~mm}$.

Discussion: WMK 6623 is a well-worn, partial premolar, possibly deciduous that appears to represent the Rhinocerotidae. A small labial cingulid is present. WMK 6635 and 6718 are cheek tooth enamel fragments. Due to their fragmentary states, a familial identification is all that is possible. However, they do indicate that representatives of the Rhinocerotidae were present in the Mogul lf.

Family Equidae Gray, 1821

Subfamily Equinae Gray, 1821

Tribe Equini Gray, 1821

Genus Dinohippus Quinn, 1955

Dinohippus cf. D. leardi (Drescher, 1941)

Referred specimen (Fig. 2): From locality WMK P-125: RP4, WMK 6712.

Age and fauna: Clarendonian, East Verdi lf.

Description: The RP4 (WMK 6712) (Fig. 2) is complete and in moderate wear (stage of wear after Kelly, 1998b). It is characterized by having the following: (1) the fossette enamel borders are very simple; (2) the protocone is well connected to the protoloph, oval in occlusal outline, well separated from the metaloph, and the anterior portion is extended only slightly anteriorly; (3) a distinct pli caballin is present; (4) the hypoconal groove is closed with only an incipient plication at its position along the posterior enamel border of the tooth, and a hypoconal lake is present; (5) the crown is moderately tapered, with the A-P dimension at the occlusal surface greater than the A-P dimension at the base of the crown; (6) the crown is slightly curved (ROC $=80 \mathrm{~mm}$ ); and (7) the cement is thick $(\sim 2 \mathrm{~mm})$. The measurements for WMK 6712 are: A-P = $29.5 \mathrm{~mm}, \mathrm{TR}=29.2 \mathrm{~mm}$, protocone A-P $=8.7 \mathrm{~mm}$, protocone $\mathrm{TR}$ $=6.7 \mathrm{~mm}$, and mesostylar crown height $=46.0 \mathrm{~mm}$.

Discussion: WMK 6712 exhibits characters that are shared with certain species of Dinohippus sensu lato (see Kelly [1998b] for detailed discussion of Dinohippus and Pliohippus). It is most similar to Dinohippus leardi and shares the following dental characters: (1) simple fossette enamel borders; (2) a closed hypoconal groove that does not extend down to the base of the crown; (3) an oval protocone connected to the protoloph; (4) a single pli caballin; (5) thick cement; and (6) a tapered crown. It differs from $D$. leardi by having a greater ROC, a slightly more persistent pli caballin, and a hypoconal lake. Although hypoconal lakes are usually absent in $D$. leardi, they are occasionally present (Kelly, 1998b). In Pliohippus, hypoconal lakes usually form when the hypoconal groove closes (Kelly, 1998b). WMK 6712 differs from the upper cheek teeth of Pliohippus by having much less curvature (ROC of Pliohippus $<40 \mathrm{~mm}$ ), a more persistent pli caballin, a protocone that is well separated from the hypocone, and larger size. These differences preclude assignment of WMK 6712 to Pliohippus.

WMK 6712 represents $D$. leardi or a species closely related to it that is at a similar evolutionary stage within the Dinohippus lineage (see Kelly, 1998b), and therefore we refer it to Dinohippus cf. D. leardi.

\section{Dinohippus sp.}

Referred specimens (Fig. 3; Table 1): From locality WMK P-102: upper cheek tooth partial fossette, WMK 6790; partial Lp3 or 4, WMK 6789; lower cheek tooth postflexid, WMK 6791. From locality WMK P-103: upper left cheek tooth fossette, WMK 6618; upper cheek tooth partial protoloph and protocone, WMK 6617; upper cheek tooth partial fossette, WMK 6619; upper cheek tooth partial ectoloph, WMK 6620; upper cheek tooth partial fossette, WMK 6769; upper cheek tooth partial fossette, WMK 6811; partial Lp2, WMK 6768; associated partial Rp3-4, WMK 6809; lower left cheek tooth postfossettid, WMK 6621; lower left cheek tooth prefossettid, WMK 6770; lower right cheek tooth prefossettid, WMK 6771; astragalus, WMK 6616. From locality WMK P-104: upper cheek tooth partial fossette, WMK 6741; upper left cheek tooth fossettes, WMK 6628; partial Rm1 or 2, WMK 6627; partial lower right cheek tooth, probably m1, WMK 6629; partial left lower cheek tooth, WMK 6725; partial lower cheek tooth, WMK 6750; astragalus, WMK 6734; astragalus, WMK 6735; astragalus, WMK 6736; first phalanx, WMK 6655; partial third phalanx (hoof), WMK 6726. From locality WMK P-107: partial right upper cheek tooth, WMK 6820; upper cheek tooth fossette, WMK 6637. From locality WMK P-127: upper left cheek tooth ectoloph and partial fossette, WMK 6721; partial Rm1 or 2, WMK 6720.

Age and fauna: Hemphillian, Mogul lf.

Description: The horse material in the Mogul lf consists of several almost complete lower cheek teeth and numerous upper and lower cheek teeth fragments (Fig. 3). Although only a few specimens are relatively complete, the morphologies exhibited by these and all of the other tooth fragments are rather consistent. This horse dental material is characterized by having the following: (1) the upper cheek teeth have only slight curvature (average $\mathrm{ROC}=\sim 80 \mathrm{~mm}$ ); (2) the upper cheek teeth fossette enamel borders are very simple, with either weakly developed single plis 

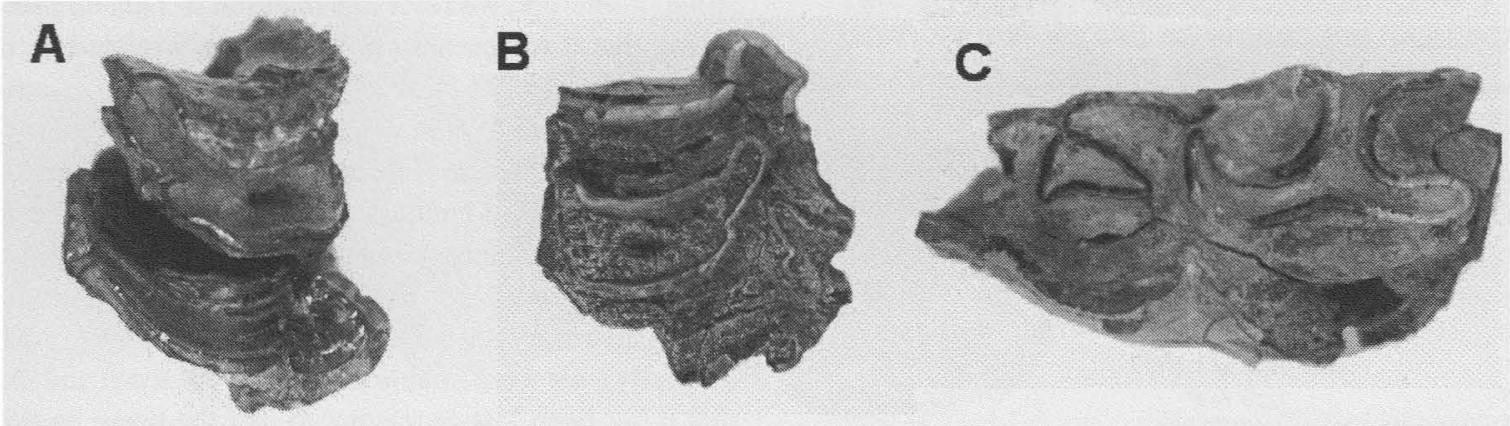

D
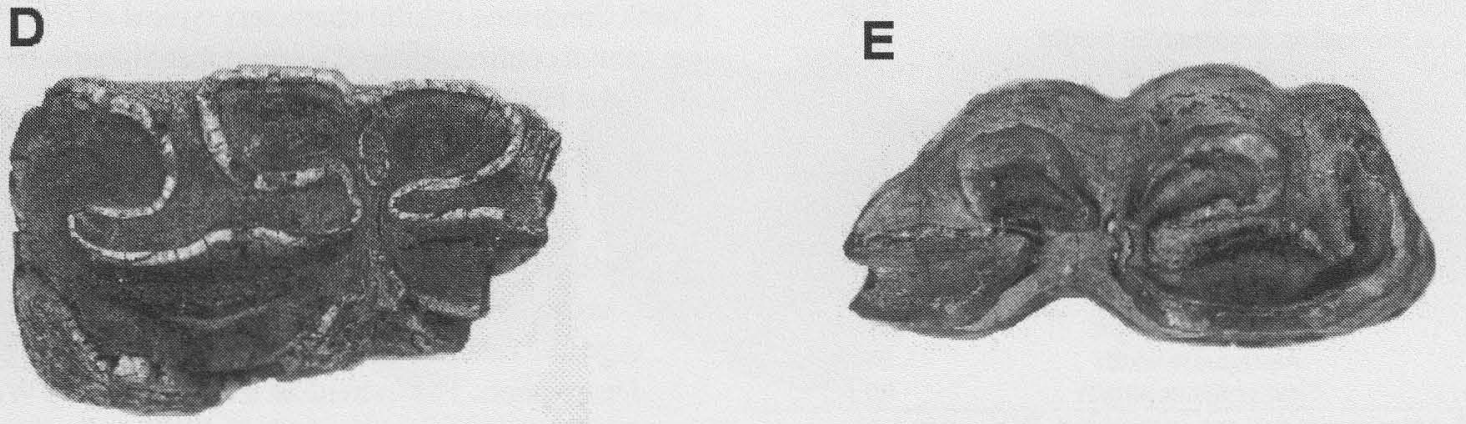

$\mathbf{F}$

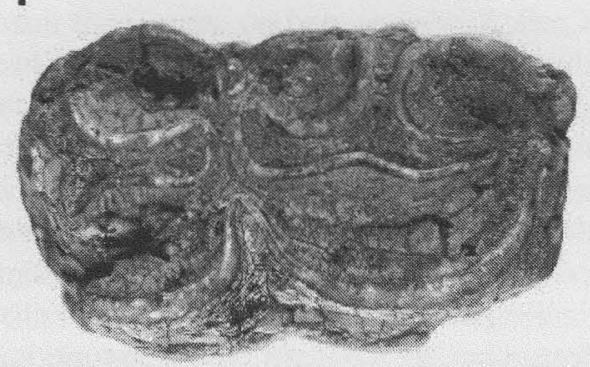

G

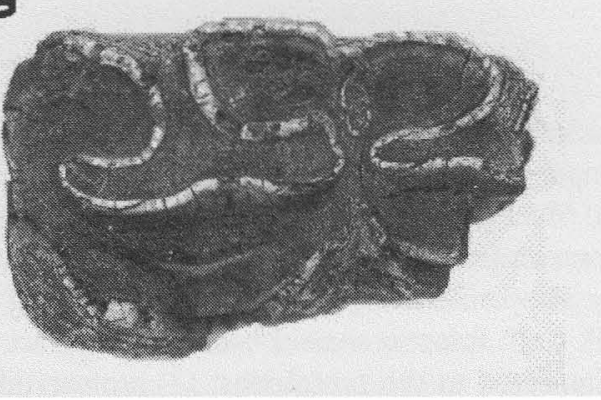

Figure 3. Dinohippus sp. from Mogul lf. (A) Partial left upper cheek tooth with protocone and fossette, WMK 6618. (B) Partial right upper cheek tooth, WMK 6820. (C) Partial Lp2, WMK 6768. (D) Partial Rm1 or 2, WMK 6720. (E) Partial Rm1 or 2, WMK 6627. (F) Partial Lp3 or 4, WMK 6789. (G) Partial Rp4, WMK 6809. All occlusal views; bar scale $=5 \mathrm{~mm}$.

prefossette and postfossette or lacking any plications; (3) the protocones are oval and well connected to the protolophs; (4) the plis caballin are single and weakly developed; (5) the lower cheek teeth are almost straight, with little curvature; (6) the prefossettid and postfossettid borders are very simple and lack plications; (7) the ectoflexids in the lower premolars do not penetrate the isthmuses between the metaconids and metastylids; (8) the linguaflexids are generally U-shaped; (9) the plis caballinid are either absent or represented by a single, very slight indentation along the ectoflexid; (10) the ectoflexids in the lower molars generally do not penetrate the isthmuses between the metaconids and metastylids (only one partial lower molar shows penetration); (11) all the lower cheek teeth in which the anterolabial portion of the tooth is preserved lack protostylids; and (12) the cement covering is thick $(>1.5 \mathrm{~mm})$. The teeth appear to have been hypsodont because even teeth in which the lower portion of the crown is broken off or teeth that are in a moderate or well-worn stage have mesostylar or metastylar heights greater than $50 \mathrm{~mm}$. In WMK 6721, most of the mesostyle is present, and it measures $64.7 \mathrm{~mm}$ in height. Measurements of selected teeth are presented in Table 1.

Appendicular elements are represented by several astragali, a first phalanx, and a partial hoof. The dimensions (Table 1) of the appendicular and dental specimens indicate that the horse of the Mogul lf was of moderate size as compared with contemporary Hemphillian Equini from other localities within the Great Basin (Macdonald, 1959; Shotwell, 1970; Azzaroli, 1988; Downs and Miller, 1994; Kelly, 2000). 
TABLE 1. MEASUREMENTS OF SELECTED DENTAL AND APPENDICULAR SPECIMENS OF DINOHIPPUS SP. FROM MOGUL LOCAL FAUNA

\begin{tabular}{lcc}
\hline \hline Specimen & Dimension measured & $\begin{array}{c}\text { Measurement } \\
(\mathrm{mm})\end{array}$ \\
\hline WMK 6618 & Fossette height & 59.6 \\
& ROC & 82.0 \\
& Protocone A-P & 5.3 \\
WMK 6811 & Protocone TR & 4.9 \\
WMK 6628 & ROC & 83.0 \\
WMK 6721 & ROC & 80.5 \\
WMK 6768 & Mesostylar height & 64.6 \\
& Lp2 A-P & 33.4 est. \\
WMK 6789 & Lp2 TR & 16.9 \\
& Lp3 or 4 A-P & 30.5 \\
WMK 6809 & Lp3 or 4 TR & 16.9 \\
WMK 6627 & Lp3 or 4 metastylid height & 47.0 \\
& Rp3 or 4 TR & 16.0 est. \\
WMK 6720 & ?Rm1 TR & 12.1 \\
& ?Rm1 metastylid height & 52.0 \\
& Rm1 or 2 A-P & 30.1 \\
WMK 6734 & Rm1 or 2 TR & 15.5 \\
& Rm1 or 2 metastylid height & 51.0 \\
WMK 6735 & Astragalus height & 53.5 \\
& Astragalus width & 53.6 \\
WMK 6726 & Astragalus height & 57.0 \\
\hline N & Astragalus width & 54.4 \\
\hline
\end{tabular}

Note: A-P-anteroposterior; est.-estimated; ROC-radius of curvature; TR-transverse.

Discussion: The horse material in the Mogul if can be confidently assigned to the subfamily Equinae and tribe Equini (see Hulbert and MacFadden, 1991; MacFadden, 1992) based on the dental characters listed previously. The teeth differ from those of the tribe Hipparionini by having the following: (1) simple upper cheek teeth fossette enamel borders; (2) protocones that are well connected to the protolophs; (3) protostylids absent; (4) plis caballinid absent or only very weakly developed; and (5) simple prefossettid and postfossettid enamel borders. They differ from those of Pliohippus by having the following: (1) cheek teeth with much less curvature (ROC of Pliohippus < $40 \mathrm{~mm}$ ); (2) protocones that are well separated from the hypocones during moderate-wear stage; (3) shallower lower molar ectoflexids that generally do not penetrate the isthmuses during moderate-wear stage; and (4) larger size.

All the dental characters exhibited by the horse material in the Mogul lf from the Hunter Creek Sandstone are seen also in species of the genus Dinohippus sensu lato (Kelly, 1998b). Specifically, the Hunter Creek equid teeth are indistinguishable in dental occlusal morphology and size to those of Dinohippus cf. D. spectans from the Coal Valley Formation of Smith Valley, Nevada (Macdonald, 1959; Kelly, 1998b). They differ from $D$. cf. D. spectans in having slightly less curvature of the upper cheek teeth, which is generally regarded as a derived character (Hulbert, 1988; Kelly, 1998b). However, until additional material is discovered, a specific diagnosis cannot be made based on the fragmentary nature of the sample from the Hunter Creek Sand- stone. Therefore, we refer this material to Dinohippus sp., recognizing that it represents a species closely related to, or possibly conspecific with, D. cf. D. spectans.

An interesting note is that Axelrod (1958) referred a partial horse tooth from the Hunter Creek Sandstone, which was collected $\sim 1.6 \mathrm{~km}(\sim 1 \mathrm{mile})$ north of Mogul, to either Hipparion or Neohipparion. Axelrod stated that this partial tooth was in the collection at the W.M. Keck Museum. During a complete curation of all vertebrate fossil specimens in the collection by one of us (Kelly), we were unable to relocate the tooth and must assume that it has been lost or misplaced. All the horse partial teeth and numerous tooth fragments in the collection from the Hunter Creek Sandstone exhibit characters typical of Dinohippus. Thus, we cannot confirm Axelrod's report that hipparionines were present in the Hunter Creek Sandstone.

Genus Equus Linnaeus, 1758

Equus idahoensis Merriam, 1918

Referred specimen (Fig. 4; Table 2): From locality WMK P-111: associated partial RP3-M1 and partial LM1-3, WMK 6634.

Age and fauna: Blancan, Byland locality.

Description: The individual teeth making up WMK 6634 are assumed to represent a single individual and were cataloged as a single specimen because of the following facts: (1) they were recovered from a small isolated pocket $(20 \times 30 \mathrm{~cm})$ within the Hunter Creek Sandstone, and no other fossil material was evident in the area; (2) they are all at the same occlusal wear stage (moderate wear); and (3) the anterior and posterior surfaces (interstitial wear facets) of successive teeth fit precisely together. The premolars are represented by a partial RP3 and RP4, which exhibit the following characters: (1) the fossette enamel borders are relatively simple, with single plis protoloph, single plis hypostyle, rounded plis protoconule, and two small plis postfossette; (2) the protocones are elongated anteroposteriorly and indented along their lingual borders; (3) the protocones are well connected to the protolophs by narrow isthmuses, the anterior portions of the protocones extend anteriorly well past the isthmuses, and the posterior portions of the protocones extend to about the middle of the metalophs; (4) a single, well-developed pli caballin is present; (5) the hypoconal grooves are well developed and extend down to near the base of the crown; and (6) there is very little curvature, and the crown is almost straight $(\mathrm{ROC}=126 \mathrm{~mm})$. The mesostylar height of the RP4 is $53.9 \mathrm{~mm}$.

The upper molars are represented by a RM1, a partial LM1, and LM2-3. The M1-2 are morphologically very similar to the upper premolars and exhibit all of the characters listed for the premolars. The M 3 differs from the M1-2 by being slightly more elongated anteroposteriorly and having a less distinct hypoconal groove. The mesostyle height of the RM1 is $53.4 \mathrm{~mm}$ and that of the LM2 is $52.6 \mathrm{~mm}$. Additional measurements for the premolars and molars are presented in Table 2.

Discussion: The cheek teeth of WMK 6634 can be confidently assigned to Equus based on the characters listed above. They differ from those of Dinohippus by having the following: 


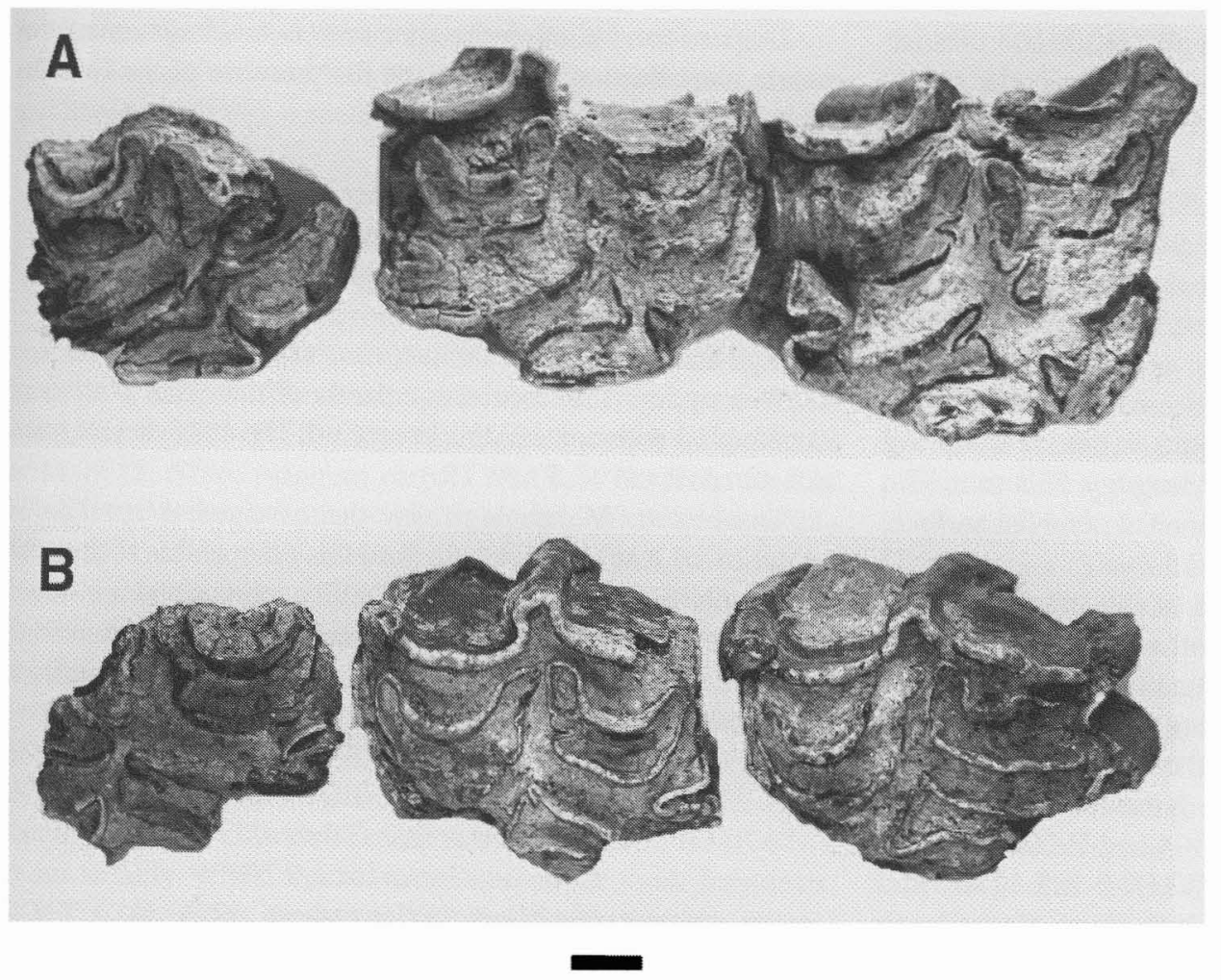

Figure 4. Equus idahoensis from Byland locality. (A) Partial RP3-M1, WMK 6634. (B) Partial LM1-M3, WMK 6634. All occlusal views; bar scale $=5 \mathrm{~mm}$.

(1) the protocones are very elongated anteroposteriorly with a well-developed indentation along the lingual borders; (2) the protocones extend anteriorly well past the isthmuses that connect the protocones to the protolophs; and (3) the crowns are straighter, with only very slight curvature. In size and dental morphology, the associated teeth of WMK 6634 are indistinguishable from those of Equus idahoensis (see Merriam, 1918; Shotwell, 1970; Azzaroli and Voorhies, 1993; Downs and Miller, 1994; Repenning et al., 1995; Kelly, 1997), and we refer them to this species.

Order Artiodactyla Owen, 1848

Family Camelidae Gray, 1821

Genus Hemiauchenia Gervais and Ameghino, 1880 cf. Hemiauchenia sp.

Referred specimens: From locality P-107: partial metapodial, WMK 6830. From locality WMK P-103: partial astragalus, WMK 6772.

Age and fauna: Hemphillian, Mogul lf.

Description: The partial metapodial is missing the distal condyles. The measurements of the metapodial are as follows; the TR proximal articular surface $=40.7 \mathrm{~mm}$, TR mid-shaft $=24.6 \mathrm{~mm}$, A-P at mid-shaft $=24.4 \mathrm{~mm}$; and the broken length (missing the distal condyles) $=290.3 \mathrm{~mm}$. The partial right astragalus is missing the lateral trochlear crest and distal astragalar facet. The height from the medial trochlear crest to the navicular facet is $65.3 \mathrm{~mm}$.

Discussion: The elongated and slender proportions of the metapodial are typical of those of Hemiauchenia. The size of the partial astragalus is within the size range of those of Hemiauchenia from the Hemphillian Smith Valley Fauna of the Coal Valley Formation, Smith Valley, Nevada (Macdonald, 1959; unpublished specimens in the LACM and UCMP). The specimens probably represent Hemiauchenia, but without additional diagnostic material, their assignment to this taxon is tentative.

Genus Megatylopus Matthew and Cook, 1909 cf. Megatylopus spp.

TABLE 2. MEASUREMENTS OF EQUUS IDAHOENSIS FROM THE BYLAND LOCALITY

\begin{tabular}{lcc}
\hline \hline Position/dimension & $\begin{array}{c}\text { A-P } \\
(\mathrm{mm})\end{array}$ & $\begin{array}{c}\text { TR } \\
(\mathrm{mm})\end{array}$ \\
\hline RP3 & 33 est. & 29 est. \\
RP3 protocone & 13.0 & 5.1 \\
RP4 & 35.4 & 31.2 \\
RP4 protocone & 13.4 & 5.8 \\
RM1 & 34.6 & 32.6 \\
RM1 protocone & 13.1 & 5.9 \\
LM1 & n.d. & n.d. \\
LM1 protocone & n.d. & n.d. \\
LM2 & 31.6 & n.d. \\
LM2 protocone & n.d. & n.d. \\
LM3 & 36.3 & 27.8 \\
LM3 protocone & 14.1 & 5.5 \\
\hline
\end{tabular}

Note: A-P-anteroposterior; n.d.-no data; TR-transverse; est.-estimated. 
Referred specimens: From locality WMK P-104: fibular tarsal, WMK 6738. From locality WMK P-106: navicular tarsal, WMK 6865. From locality WMK P-105: partial distal metapodial, WMK 6632.

Age and fauna: Hemphillian, Mogul lf and latest Hemphillian or earliest Blancan, unnamed assemblage from WMK P-105.

Description: The tarsals and partial metapodial are characterized by their large size. The fibular tarsal is complete with the following dimensions; height $=55.5 \mathrm{~mm}$ and width $=31.7 \mathrm{~mm}$. The navicular tarsal is missing small portions of bone from the anterior medial and posterior medial aspects. It has the following dimensions: height $=34.0 \mathrm{~mm}$ and A-P length $=53.3 \mathrm{~mm}$. The partial distal metapodial is missing the medial condylar surface. The lateral condylar A-P dimension is $40.5 \mathrm{~mm}$.

Discussion: The robust proportions of the tarsals and partial metapodial indicate the presence of a large camel within the Mogul if and the unnamed assemblage from locality WMK $\mathrm{P}-105$. These elements are significantly larger than those of Hemiauchenia and Alforjas, but smaller than those of Gigantocamelus (see Harrison, 1979; Kelly, 1994, 1997). It cannot be determined whether the specimens from WMK P-104 and P-106 represent the same species as the specimen from WMK P-105. In size and morphology, they all compare well with those of Megatylopus from the Hemphillian Smith Valley Fauna of the Coal Valley Formation, Smith Valley, Nevada (Macdonald, 1959; unpublished specimens in the collections of the LACM and UCMP). Thus, we tentatively assign this sample to cf. Megatylopus spp.

Camelidae, genus and species indeterminate

Referred specimen: From locality WMK P-132: partial upper molar ectoloph, WMK 6852.

Age and fauna: Clarendonian, East Verdi lf.

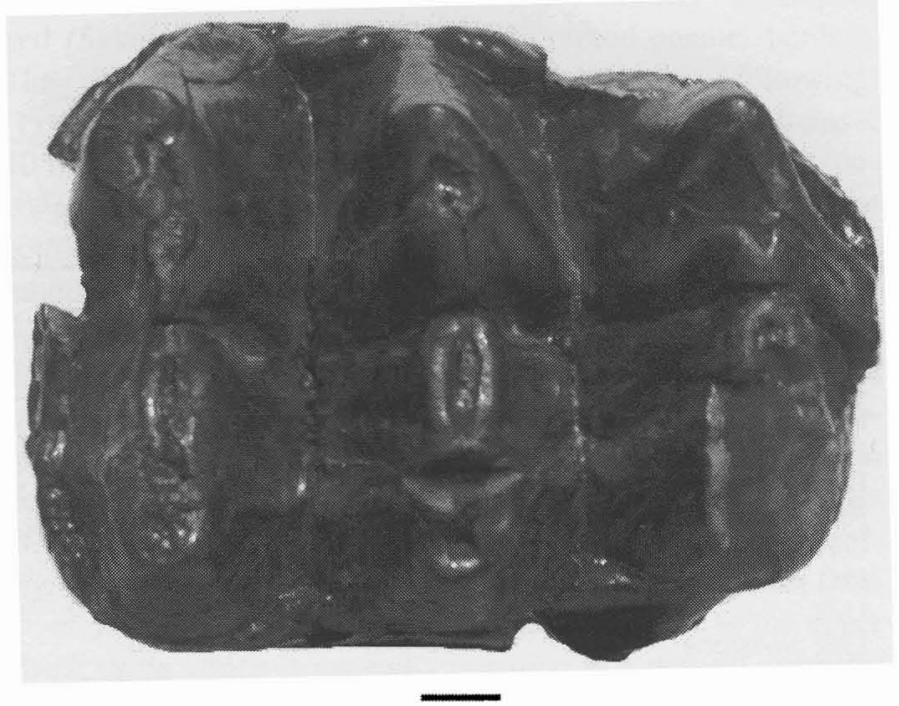

Figure 5. Mammut sp. from Mogul If. LM2, WMK 6968, occlusal view. Bar scale $=10 \mathrm{~mm}$.
Discussion: Although the specimen is too fragmentary for generic identification, it documents the presence of the Camelidae in the East Verdi lf.

Family Antilocapridae Gray, 1966

?Antilocapridae, genus and species indeterminate

Referred specimen: From locality WMK P-110: distal metapodial condyle, WMK 6654.

Age and fauna: Clarendonian, East Verdi If.

Description: The specimen consists of the distal portion of a metapodial with one condyle preserved. The condyle measures $24.3 \mathrm{~mm}$ A-P and $12.8 \mathrm{~mm}$ TR.

Discussion: Morphologically, the metapodial condyle is typical of the Antilocapridae. In size, it is comparable to those of the Hemphillian to Rancholabrean Antilocaprinae, and it is larger than those of the Barstovian to Clarendonian Merycodontinae. However, even a familial assignment is difficult, so we refer it questionably to the Antilocapridae.

Order Proboscidea Illiger, 1811

Family Mammutidae Cabrera, 1929

Mammut Blumenbach, 1799

Mammut (= Pliomastodon Osborn, 1926) sp.

Referred specimen (Fig. 5): From locality WMK 107: LM2, WMK 6968.

Age and fauna: Hemphillian, Mogul lf.

Description: The upper molar is in early wear and has small portions of the anterior and posterior enamel missing. There are three primary transverse lophs that are well separated by complete valleys that are open labially and lingually (Fig. 5). The transverse lophs lack any trefoiling. Small, but distinct anterior and posterior cingula are present. Small, intermittent cingula are also present between the labial aspects of the transverse lophs. The measurements of WMK 6968 are $113 \mathrm{~mm}$ A-P and $86 \mathrm{~mm}$ TR.

Discussion: Buwalda (1914) described a partial mastodon tooth that was later determined by Axelrod (1958) to have been recovered from an interval estimated to be $\sim 400-500 \mathrm{ft}(\sim 120$ $150 \mathrm{~m}$ ) above the Verdi Flora locality. He questionably assigned this tooth to Tetrabelodon. Stirton (1940) noted that this tooth was similar to Gomphotherium simpsoni (Stirton, 1939) but stressed that the tooth was not diagnostic. Subsequently, a second, more complete, mastodon tooth (WMK 6968, Fig. 5) was recovered from an exposure that was reported to occur $\sim 600 \mathrm{ft}(\sim 180 \mathrm{~m})$ stratigraphically below the Verdi Flora and $400 \mathrm{ft}(\sim 120 \mathrm{~m})$ above mafic lavas (Axelrod, 1958). Based on limited WMK locality data, this second tooth appears to have come from the middle part of the formation at locality WMK P-107. WMK 6968 was reported to be a left M2 of a true mammutid mastodon (personal commun. from D.E. Savage in Axelrod, 1958, p. 158). Savage thought it might represent Miomastodon or Pliomastodon. Lambert and Shoshani (1998) now regard Miomastodon as a junior synonym of Zygolophodon and Pliomastodon a junior synonym of Mammut. Based on size and the simple, trilophodont occlusal pattern with open valleys between the lophs, WMK 6968 can be confidently referred 
to Mammut (= Pliomastodon). However, because of morphological similarities between bunolophodont proboscideans (Lambert and Shoshani, 1998), a specific diagnosis is not possible.

Family Gomphotheriidae Hay, 1922 or Mammutidae Cabrera, 1929

Genus and species indeterminate

Referred specimens: From locality WMK P-102: cheek tooth enamel fragments, WMK 6607-6609, 6719, 6796-6801. From locality WMK P-103: cheek tooth enamel fragments, WMK 6614, 6624, 6774-6778, 6816-6817, 6819; partial tusks, WMK 6614-6615, 6786; magnum carpal, WMK 6773. From locality WMK P-104: cheek tooth enamel fragments, WMK 6626, 67286732, 6751-6767, 6787-6788. From locality WMK P-105: cheek tooth enamel fragments, WMK 6782-6783. From locality WMK P-106: cheek tooth enamel fragments, WMK 6633, 6866-6866; associated tusk fragments, WMK 6864; humerus, WMK 6967. From locality WMK P-107: cheek tooth enamel fragments, WMK $6640-6647,6649,6651-6653,6833-6851,6858$. From locality WMK P-108: cheek tooth enamel fragment, WMK 6853. From locality WMK P-109: cheek tooth enamel fragment, WMK 6717. From locality WMK P-110: associated cheek tooth fragments, WMK 6781. From locality WMK P-125: cheek tooth enamel fragments, WMK 6713-6715. From locality WMK P-127: cheek tooth enamel fragments, WMK 6723-6724. From locality WMK P-128: cheek tooth enamel fragments, WMK 6779-6780. From locality WMK P-129: cheek tooth enamel fragments, WMK 6806-6807. From locality WMK P-131: cheek tooth enamel fragments, WMK 6854-6857. From locality WMK P-132: associated cheek tooth fragments, WMK 6863. From locality WMK P-133: cheek tooth enamel fragments, WMK 6859-6862. From locality WMK P-134: partial cervical vertebra, WMK 6868; partial scapula (glenoid fossa), WMK 6869. From locality WMK P-167: partial tusk, WMK 6966.

Age and faunas: Clarendonian, East Verdi If; Hemphillian, Mogul If; and latest Hemphillian or earliest Blancan, unnamed assemblage from WMK P-105.

Discussion: Proboscidean cheek tooth fragments are by far the most common vertebrate fossils throughout the section of the Hunter Creek Sandstone below the thick lacustrine facies in the upper part of the formation. Almost every locality yielded specimens. The enamel morphology of the cheek tooth fragments indicates that they could represent either the Gomphotheriidae or Mammutidae.

\section{BIOSTRATIGRAPHY}

At least three North American land mammal ages (Woodburne, 1987, 2004) are represented by fossils from the Hunter Creek Sandstone (Fig. 6). These include the Clarendonian (late Miocene), the Hemphillian (late Miocene to earliest Pliocene), and the Blancan (Pliocene).

The localities that occur from $\sim 75 \mathrm{~m}$ below the mafic lavas to $\sim 500 \mathrm{~m}$ above these lavas $(-75-500 \mathrm{~m}$ levels in Fig. 6) yielded the East Verdi lf, which includes Dinohippus cf. D. leardi, Camelidae, ?Antilocapridae, and Mammutidae or Gomphotheriidae. The most productive localities within this stratigraphic interval occur on private lands north of the Truckee River and east the community of Verdi (Fig. 1). These localities can be accurately placed within the stratigraphic section relative to the dated mafic lavas and the lacustrine facies. The stratigraphic positions of WMK P-133 and P-134, south of the Truckee River, are less confident because they cannot be directly correlated relative to the mafic lavas. However, WMK P-133 and P-134 do occur very low in the section in silty sandstones that directly overlie a conglomerate that appears to correlate with the conglomerate facies interbedded with mafic lavas dated at ca. $10 \mathrm{Ma}$ in the Steamboat Ditch section (Trexler et al., 2000). The only fossils recovered from WMK P-133 and P-134 are fragments of cheek teeth representing Equidae and Gomphotheriidae or Mammutidae. The stratigraphic position of locality WMK P-167, which occurs along Steamboat Ditch, is more confident because it can be tied to the measured Steamboat Ditch section (Trexler, et al., 2000).

The most biostratigraphically informative species in the East Verdi if is Dinohippus cf. D. leardi. Dinohippus leardi is known only from the following Clarendonian faunas: upper localities of the Iron Canyon Fauna $(\mathrm{Cl} 2)$ and Ricardo Fauna $(\mathrm{Cl} 3)$, Dove Spring Formation, California; North Tejon Hills Fauna (Cl3), Chanac Formation, California; and the Black Hawk Ranch Quarry (C13), Green Valley Formation, California (Savage, 1955; Drescher, 1941; Richey, 1948; Whistler and Burbank, 1992; Kelly, 1998b; Tedford et al., 2004). Based on biostratigraphic correlation, radioisotopic and paleomagnetic data constraints, the taxon-range chron for $D$. leardi in these formations is late-medial to late Clarendonian (Cl2-Cl3), or ca. 10.8-9.0 Ma (Savage, 1955; Drescher, 1941; Whistler and Burbank, 1992; Wilson and Prothero, 1997; Kelly, 1998b; Prothero and Tedford, 2000; Tedford et al., 2004). Kelly (1998b) provided cladistic analyses that documented the progressive acquisition of apomorphies within the Dinohippus clade. These analyses provided also an evolutionary and chronological framework for the succession of dental characters within the clade. Dinohippus cf. D. leardi is morphologically very similar to $D$. leardi and either represents $D$. leardi or a species closely related to $D$. leardi that is at a similar stage of evolution within the Dinohippus clade (see Kelly, 1998b), suggesting a similar age constraint for the East Verdi If. The stratigraphic positions of the localities that yielded the East Verdi If, relative to the dated mafic lavas (ca. $10 \mathrm{Ma}$ ), are also consistent with a late-medial to late Clarendonian age (ca. 10.8-9 Ma) for the fauna.

The Mogul If was collected from localities that occur from $\sim 850-1350 \mathrm{~m}$ in the measured section (Fig. 6), and it includes Dinohippus sp., Rhinocerotidae, Camelidae (at least two species), Mammut (= Pliomastodon) sp., and possibly Gomphotheriidae. The most productive localities within this interval were WMK P-103, P-104, P-127 (north of the community of Mogul), and WMK P-107 (southwest of Mogul). Dinohippus sp. is the most biostratigraphically informative taxon and is most similar to Dinohippus cf. D. spectans of the Smith Valley Fauna, Coal 


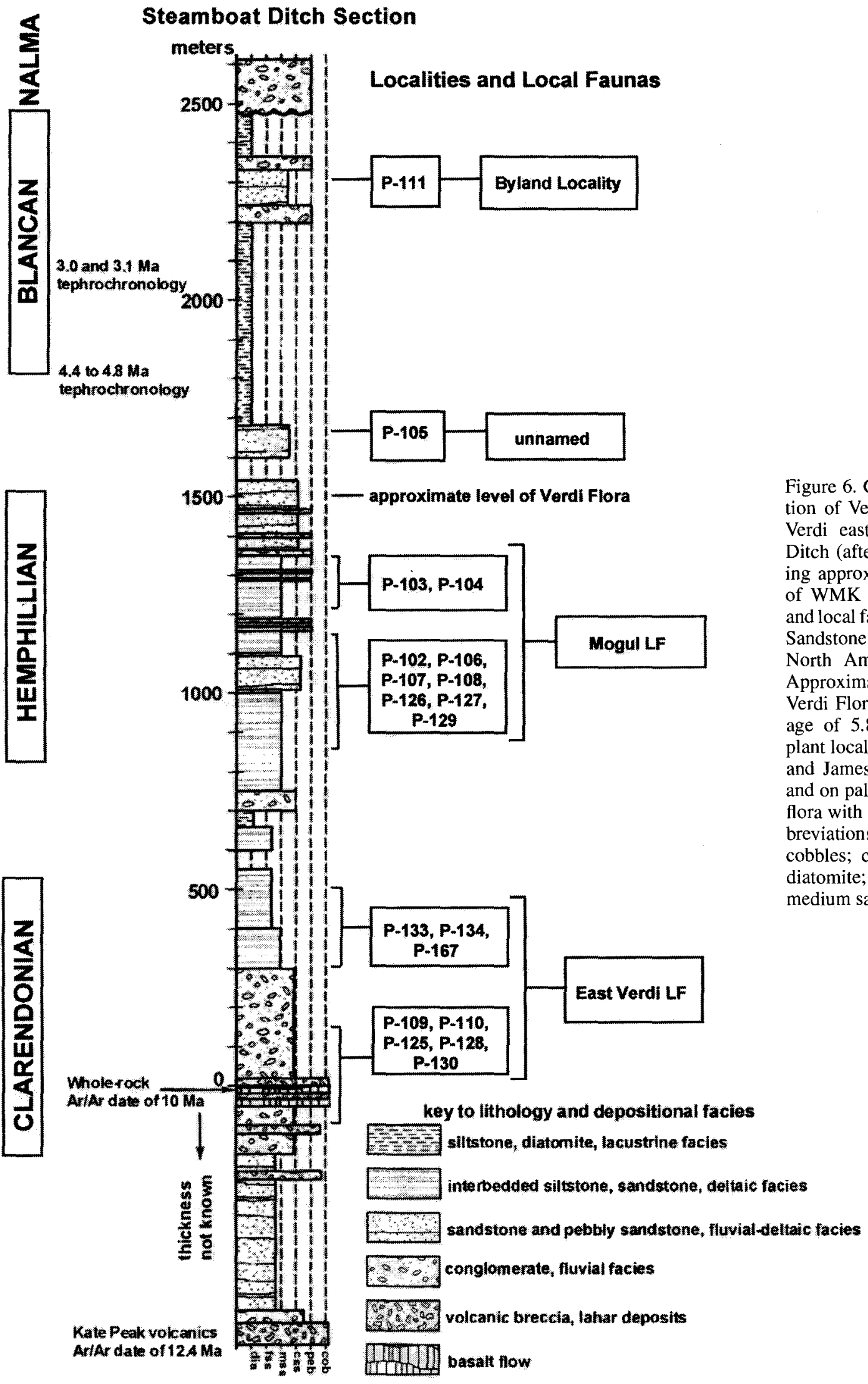

Figure 6. Generalized stratigraphic secof Verdi Basin in a transect from east to Reno along Steamboat proximate stratigraphic positions $P$ vertebrate fossil localitie al faunas within the Hunter Creek (If-local fauna; NALMAArth American land mammal age). Aproximate stratigraphic position of is based on a radioisotopic $5.85 \mathrm{Ma}$ (corrected) from the cality (Axelrod, 1958; Evernden James, 1964; Schorn et al., 1994) paleobotanical correlation of the with other Hemphillian floras. Abare: BT-basal tuff; $\mathrm{cob}$ -coarse sandstone; diaatomite; fss-fine sandstone; mssedium sandstone; peb-pebbles. 


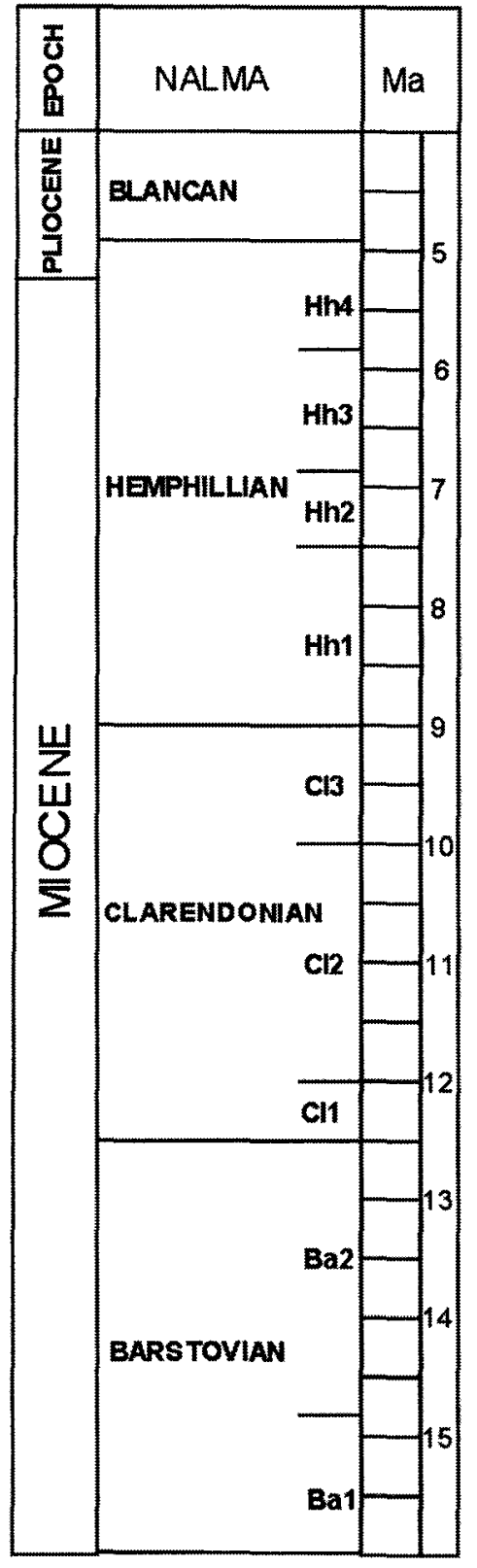

Mickey Canyon to Wilson Canyon, Smith Valley

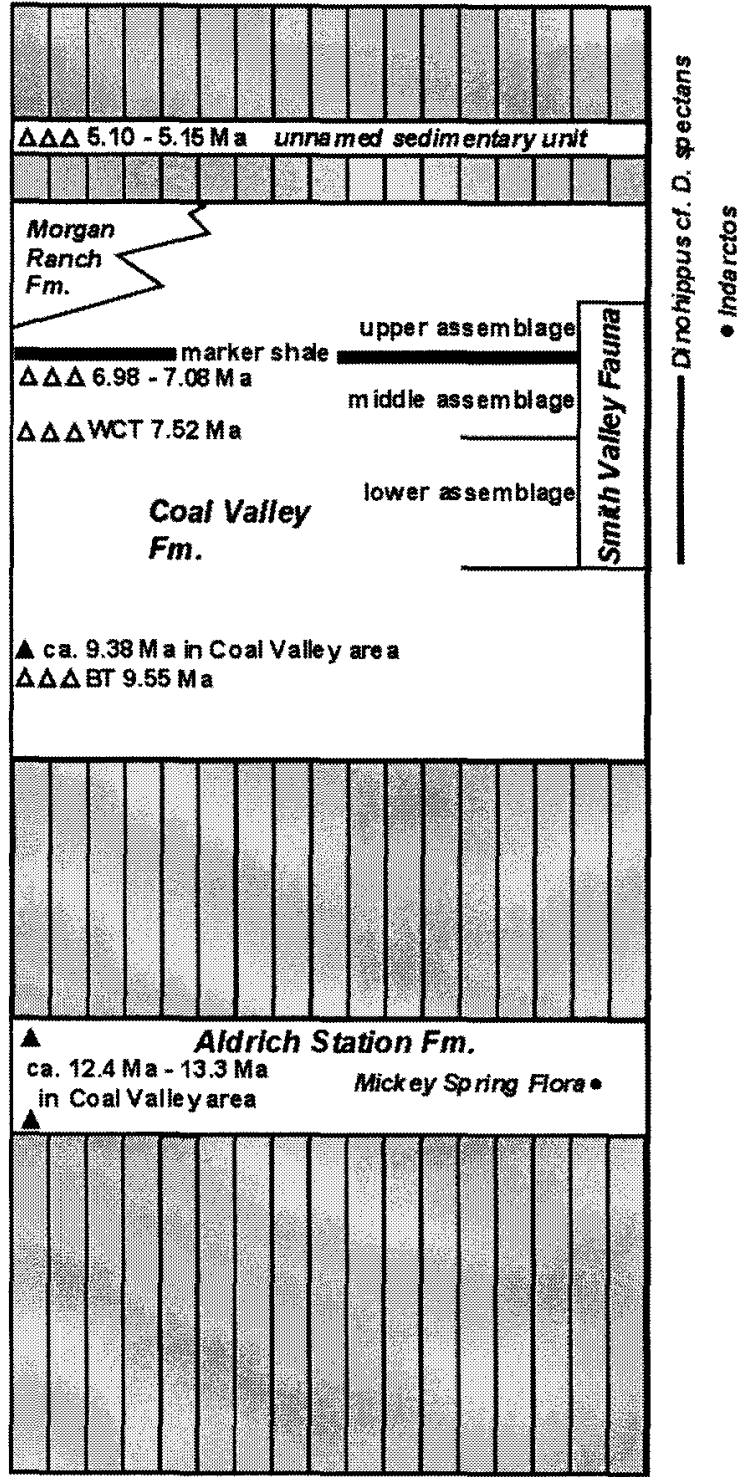

Figure 7. Schematic chart of generalized section from Mickey Canyon to Wilson Canyon, Smith Valley, Nevada, showing the biostratigraphy, chronostratigraphy, and stratigraphic relationships of formations exposed in this area. Open triangles represent tuffs with radioisotopic ages from the section (see text), and filled triangles (black) represent tuffs with radioisotopic ages (corrected) that are extrapolated onto the section from the type Coal Valley and Aldrich Station Formations, Coal Valley, Nevada (Gilbert and Reynolds, 1973). Shaded, vertically lined intervals represent unconformities. The stratigraphic levels that yielded Indarctos and the taxonrange chron for Dinohippus cf. D. spectans are shown on the right. Subzones of North American land mammal ages (NALMA) follow Tedford et al. (2004). WCT-Wilson Canyon Tuff.

Valley Formation, Smith Valley, Nevada (Macdonald, 1959; Kelly, 1998b).

The age of the Smith Valley Fauna is constrained biostratigraphically and radioisotopically. Three marker horizons have been previously recognized in the Smith Valley section (Fig. 7). Using the lowest marker horizon as a datum (basal tuff, $0 \mathrm{~m}$ ) and field data with estimated stratigraphic levels, they are: (1) a basal tuff that occurs $\sim 350 \mathrm{~m}$ below the lowest occurrence of mammals on the eastern edge of Smith Valley, which yielded a K-Ar (biotite) age of $9.55 \mathrm{Ma}$ (Evernden et al., 1964; $2 \sigma$ errors not provided); (2) the Wilson Canyon Tuff at $\sim 650 \mathrm{~m}$, which yielded $\mathrm{a}^{40} \mathrm{Ar} /{ }^{39} \mathrm{Ar}$ (plagioclase) age of $7.52 \pm 0.08 \mathrm{Ma}$ (Swisher, 1992); and (3) a marker shale (Gilbert and Reynolds, 1973) at $\sim 850 \mathrm{~m}$. Chris Henry (2005, personal commun.) recently dated two additional tuffs (CV-427 and CV-517) that were collected by one of us (Kelly) from the Coal Valley Formation in upper Petrified Canyon, Smith Valley. These tuffs occur in the interval between the Wilson Canyon Tuff and the marker shale at $130 \mathrm{~m}$ (CV-427) and $160 \mathrm{~m}$ above (CV-517) the Wilson Canyon Tuff. The tuffs yielded ${ }^{40} \mathrm{Ar} /{ }^{39} \mathrm{Ar}$ ages of $7.08 \pm 0.01 \mathrm{Ma}(\mathrm{CV}-427$, sanidine) and $6.98 \pm 0.01 \mathrm{Ma}(\mathrm{CV}-517$, sanidine) and are consistent with the ${ }^{40} \mathrm{Ar}{ }^{\beta 9} \mathrm{Ar}$ age of the underlying Wilson Canyon Tuff. Furthermore, the basal tuff in Smith Valley may be a correlative of a tuff with a $\mathrm{K}-\mathrm{Ar}$ (hornblende) age of $9.38 \pm 0.44 \mathrm{Ma}$ that occurs in 
the type Coal Valley Formation, Coal Valley, Nevada, and overlies the type Coal Valley Fauna of Clarendonian age (Gilbert and Reynolds, 1973). Gilbert and Reynolds (1973) reported two K-Ar ages of $5.15 \pm 0.26 \mathrm{Ma}$ (hornblende) and $5.10 \pm 0.35 \mathrm{Ma}$ (biotite) for a tuff from an unnamed sedimentary unit that unconformably overlies the Coal Valley Formation in Smith Valley. Taxa included in the Smith Valley Fauna were collected from three stratigraphic intervals (Macdonald, 1959; locality data at the LACM and UCMP): (1) from $~ 350 \mathrm{~m}$ above the basal tuff to just below the Wilson Canyon Tuff at $\sim 650 \mathrm{~m}$; (2) from the interval between the Wilson Canyon Tuff and the marker shale at $\sim 650$ $850 \mathrm{~m}$; and (3) from just above the marker shale to $\sim 950 \mathrm{~m}$. A schematic chart of the stratigraphic relationships of the section in the vicinity of Mickey Canyon northward to Wilson Canyon, Smith Valley, is shown in Figure 7.

Tedford et al. (2004, 6.2) regarded the Smith Valley Fauna as early Hemphillian in age (Hh1, ca. 9.0-7.5 Ma) based on its faunal content and on the K-Ar age from the basal tuff (9.55 Ma). However, the bear Indarctos, one of several taxa whose first occurrences were used by Tedford et al. (2004) to define the beginning of the late-early Hemphillian ( $\mathrm{Hh} 2$, ca. 7.5-6.8 Ma), was collected from the upper assemblage of the Smith Valley Fauna (Macdonald, 1959; Hunt, 1998), above the marker shale (>850 m, Fig. 7) and new dated tuffs. The taxon-range chron for Indarctos is from the late-early Hemphillian to early-late Hemphillian (Hh2-Hh3), or ca. 7.5-6.0 Ma (Hunt, 1998). The occurrence of Indarctos above the marker shale and the ${ }^{40} \mathrm{Ar} /{ }^{39} \mathrm{Ar}$ ages for the Wilson Canyon Tuff (7.52 Ma) and the two tuffs (7.08 and $6.98 \mathrm{Ma}$ ) between the Wilson Canyon Tuff and the marker shale strongly suggest, contrary to Tedford et al. (2004, their Fig. 6.2), a late-early Hemphillian or younger age for strata above the Wilson Canyon Tuff. A detailed systematic analysis of all taxa comprising the middle assemblage is required to determine an unequivocal biochron subage assignment for this assemblage, and, because this is not yet available, we provisionally refer it to the late-early Hemphillian (Hh2).

Based on the overall taxonomic composition of the Smith Valley Fauna (Macdonald and Pelletier, 1958; Macdonald, 1959; Hunt, 1998), the stratigraphic distribution of fossils relative to the radioisotopically aged tuffs within the Smith Valley section, and the presence of Inarctos above the marker shale, the Smith Valley Fauna probably spans the early to late-early Hemphillian or younger (Hh1 to possibly $\mathrm{Hh} 3$, ca. 8.5 to at 6.5 Ma). Kelly (1998b) determined that the dental morphology of Dinohippus cf. D. spectans of the Coal Valley Formation is more derived than that of the Clarendonian $D$. leardi, but less derived than those of the late Hemphillian D. leidyanus and latest Hemphillian D. mexicanus. In the Smith Valley section, Dinohippus cf. D. spectans occurs in the lower and middle faunal assemblages and is restricted to a stratigraphic interval (Fig. 7) from $\sim 300 \mathrm{~m}$ below the Wilson Canyon Tuff to $\sim 30 \mathrm{~m}$ below the marker shale (Macdonald, 1959; specimen and locality data from the LACM and UCMP). Following the previous discussion, this interval is mostly early Hemphillian (Hh1), but it also appears to include part of the late-early Hemphillian (Hh2) above the Wilson Canyon Tuff.

East of Smith Valley, Dinohippus cf. D. spectans has been recorded in the Yerington If of the Coal Valley Formation (Macdonald and Pelletier, 1958; specimen and locality data from the LACM and UCMP) from a stratigraphic interval $\sim 100 \mathrm{~m}$ below the marker shale to $\sim 43 \mathrm{~m}$ below the marker shale (the base of the section in this area is covered by alluvium), which is consistent with its stratigraphic range in Smith Valley.

The Smith Valley Fauna correlates well with the Thousand Creek Fauna from the Thousand Creek Formation, Washoe County, Nevada, indicating that these faunas are of similar age (Furlong, 1932; Shotwell, 1955; Korth, 1999; Tedford et al., 2004). Perkins et al. (1998) determined that an ash overlying the Thousand Creek Fauna correlated geochemically with the Rattlesnake tuff, which elsewhere has $a^{40} \mathrm{Ar} /{ }^{39} \mathrm{Ar}$ (sanidine) age of $7.05 \pm 0.01 \mathrm{Ma}$ (Streck and Grunder, 1995). Perkins et al. (1998) identified also two ashes from the fossil-producing part of the section at Thousand Creek that were correlated geochemically to the Rush Valley ash and Alamo ash, which they extrapolated to be $7.90 \pm 0.50 \mathrm{Ma}$ and $8.00 \pm 1.00 \mathrm{Ma}$ in age, respectively. These ash dates are consistent with the geochronology of Smith Valley.

All of the above data indicate that the taxon-range chron for Dinohippus cf. D. spectans in the Coal Valley Formation in Smith Valley and east of Smith Valley is ca. 8.5-7.0 Ma, or early to late-early Hemphillian (Hh1 to Hh2). The close morphological similarity between $D$. cf. $D$. spectans from the Coal Valley Formation and Dinohippus sp. from the Hunter Creek Sandstone, including similar derived dental character states relative to the Clarendonian D. leardi (see Kelly, 1998b), suggests they are closely related species or are conspecific. This, in turn, suggests that the Mogul If may be of a similar age. In addition, the relative stratigraphic positions of the localities that yielded the Mogul If, which occur between ${ }^{40} \mathrm{Ar} /{ }^{39} \mathrm{Ar}$ ages of ca. $10 \mathrm{Ma}$ and tephrochronologic ages of 4.4-4.8 Ma, are also consistent with a Hemphillian age.

At least two species of camel are represented in the Mogul If, one very large-sized camel and a medium-sized camel. Based on size and morphology, the large camel probably represents Megatylopus, whereas the medium-sized camel probably represents Hemiauchenia. Both of these camels are found commonly in Hemphillian faunas of the Great Basin (Macdonald, 1959; Shotwell, 1970; Kelly, 1997, 1998a, 2000), and their presence is consistent with a Hemphillian age estimate for the Mogul If.

North of the community of Mogul, a single locality (WMK $\mathrm{P}$-105) was discovered high in the section in a dark brown sandstone bed that underlies the thick lacustrine facies of diatomaceous shale and siltstone (Fig. 6). WMK P-105 occurs $\sim 75 \mathrm{~m}$ stratigraphically below ash beds within the lacustrine facies that were tephrochronologically dated at 4.4-4.8 Ma (Trexler et al., 2000). This locality yielded only a partial camel metapodial questionably referred to cf. Megatylopus and several bunolophodont proboscidean cheek tooth fragments. The occurrence of Megatylopus is consistent with a Hemphillian or Blancan age, 
and the stratigraphic position of WMK P-105 relative to the ash dates suggests either a latest Hemphillian or earliest Blancan age. Because the sample from WMK P-105 is meager, we do not assign a faunal name.

The Blancan is confidently represented by one locality, the Byland locality (WMK P-111), which occurs on the east side of the Verdi Basin and is named in honor of Mr. Al Byland of Reno, Nevada, for allowing us access to his property. The single specimen (WMK 6634) from the Byland locality consists of associated horse upper cheek teeth that we refer to Equus idahoensis. Equus idahoensis is a common taxon in late Blancan faunas of the Pacific Coast and Great Basin that range from ca. 2.8 to $2.2 \mathrm{Ma}$ in age (Shotwell, 1970; Downs and Miller, 1994; Azzaroli and Voorhies, 1993; Kelly, 1994; Repenning et al., 1995), and it indicates a late Blancan age for the Byland locality. Tephrochronologic ages of 3.0 and 3.1 Ma have been reported from ashes that occur $\sim 100 \mathrm{~m}$ stratigraphically below the Byland locality (Trexler et al., 2000) within the thick lacustrine facies composed of diatomite and siltstone (Fig. 6), and these corroborate a Blancan age.

\section{CONCLUSIONS}

Twenty-three WMK localities yielding mammalian fossils are now known from the Hunter Creek Sandstone in the Verdi Basin, including 21 localities found during the course of this study. Although, many of the fossils are fragmentary, several specimens preserve morphology adequate for generic identification and specific conferral. These specimens, which are primarily horses, allow for the recognition of three North American land mammal ages, including the Clarendonian (late Miocene), the Hemphillian (late Miocene to earliest Pliocene), and the Blancan (Pliocene). We recognize two mammalian assemblages from the Hunter Creek Sandstone, the East Verdi and Mogul lfs. Based on faunal content, the East Verdi and Mogul lfs are late-medial to late Clarendonian $(\mathrm{Cl} 2-\mathrm{Cl} 3)$ and early to possibly late-early Hemphillian (Hh1-Hh2) in age, respectively. In addition, a specimen from the Byland locality, higher in the section, indicates a late Blancan (V) age for this level. The biostratigraphy of the local faunas is consistent with the chronostratigraphy determined by tephrochronologic and radioisotopic methods for the Hunter Creek Sandstone. A meager sample of material from WMK P-105 may represent an additional unnamed assemblage of latest Hemphillian or earliest Blancan age.

The most productive vertebrate fossil localities occur north of the Truckee River and the community of Mogul on private lands. South of the Truckee River in the Humbolt-Toiyabe National Forest, most of the vertebrate fossil localities yielded only fragmentary specimens, and because of local faulting and incomplete exposure, they are subject to greater stratigraphic uncertainty.

The consistent presence of both browsing (Camelidae and bunolophodont proboscideans) and grazing (Equidae) taxa through the late Clarendonian and Hemphillian portions of the Hunter Creek Sandstone suggests a relatively stable local paleoenvironment for at least 5 m.y. The combination of browsers and grazers suggests that the paleoenvironment was characterized by grasslands or open woodlands, probably with thicker woodlands or riparian vegetation along perennial streams and lakes.

\section{ACKNOWLEDGMENTS}

We are indebted to Jim Trexler and Pat Cashman of the University of Nevada, Reno, and Larry Garside of the Nevada Bureau of Mines and Geology, Reno, for their considerable help in providing information on the geology and stratigraphy of the Hunter Creek Sandstone. We are particularly grateful to Chris Henry of the Nevada Bureau of Mines and Geology, Reno, for his many constructive comments and for allowing us to cite his unpublished radioisotopic data for Smith Valley. We are also grateful to the late Tom Lugaski for his help with specimen curation at the W.M. Keck Museum and to Joseph Lintz for help in relocating a fossil locality. We give special thanks to Terry Birk of the Carson Ranger District, U.S. Forest Service, for his support of this study and for his considerable help in obtaining a collecting permit. Christopher Bell of the Department of Geological Sciences, University of Texas, Austin, and Donald Prothero of Department of Geology, Occidental College, Los Angeles, provided constructive comments and advice on the original draft of this report. Collections at the University of California, Berkeley, Museum of Paleontology, and the Natural History Museum of Los Angeles County were made available by Patricia Holroyd and Samuel McLeod, respectively.

\section{REFERENCES CITED}

Aubry, M.P., Berggren, W.A., Van Couvering, J.A., and Steininger, F., 1999, Problems in chronostratigraphy: Stages, series, unit and boundary stratotypes, global stratotype section and point and tamished golden spikes: Earth-Science Reviews, v. 46, p. 99-148, doi: 10.1016/S0012-8252(99)00008-2.

Axelrod, D.I., 1956, Mio-Pliocene Floras from West-Central Nevada: University of California Publications in Geological Sciences, v. 33, 322 p.

Axelrod, D.I., 1958, The Pliocene Verdi Flora of Western Nevada: University of California Publications in Geological Sciences, v. 34, p. 91-160.

Azzaroli, A., 1988, On the equid genera Dinohippus Quinn 1955 and Pliohippus Marsh 1874: Gollettino della Societa Palaeontologica Italiana, v. 27, p. $61-72$.

Azzaroli, A., and Voorhies, M.R., 1993, The genus Equus in North America. The Blancan species: Palaeontographia Italica, v. 80, p. 175-198.

Bell, C.J., Lundelius, E.L., Jr., Barnosky, A.D., Graham, R.W., Lindsay, E.H., Ruez, D.R., Jr., Semken, H.A., Jr., Webb, S.D., and Zakrzewski, R.J., 2004, The Blancan, Irvingtonian, and Rancholabrean mammal ages, in Woodburne, M.O., ed., Late Cretaceous and Cenozoic Mammals of North America, Biostratigraphy and Geochronology: New York, Columbia University Press, p. 232-314.

Bingler, E., 1975, Guidebook to the Quaternary geology along the western flank of the Truckee Meadows, Washoe County, Nevada: Nevada Bureau of Mines and Geology Report, v. 22, p. 1-14.

Buwalda, J.P., 1914, A proboscidean tooth from the Truckee beds of western Nevada: University of California Publications, Bulletin of the Department of Geological Sciences, v. 8, p. 305-308.

Dalrymple, G.B., 1979, Critical tables for conversion of K-Ar ages from old to new constants: Geology, v. 7, p. 558-560, doi: 10.1130/0091-7613(1979) 7<558:CTFCOK>2.0.CO;2.

Downs, T., and Miller, G.J., 1994, Late Cenozoic equids from the Anza-Borrego Desert of California: Natural History Museum of Los Angeles County: Contributions in Science, no. 440, p. 1-90.

Drescher, A.B., 1941, Later Tertiary Equidae from the Tejon Hills, California: Carnegie Institution of Washington Publication, v. 530, p. 1-23. 
Eisenmann, V., Alberdi, M.T., De Giuli, C., and Staesche, U., 1988, Methodology, in Woodburne, M.O., and Sondarr, P., eds., Studying Fossil Horses: Leiden, E.J. Brill, p. 1-9.

Evernden, J.F., and James, G.T., 1964, Potassium-argon dates and the Tertiary floras of North America: American Journal of Science, v. 262, p. 945-974.

Evernden, J.F., Savage, D.E., Curtis, G.H., and James, G.T., 1964, Potassiumargon dates and the Cenozoic mammal chronology of North America: American Journal of Science, v. 262, p. 145-198.

Furlong, E.L., 1932, Distribution and description of skull remains of the Pliocene antelope Sphenophalos from the northern Great Basin Province: Carnegie Institution of Washington Publication, v. 418, p. 27-38.

Garside, L.J., Castor, S.B., Henry, C.D., and Faulds, J.E., 2000, Structure, volcanic stratigraphy, and ore deposits of the Pah Pah Range, Washoe County, Nevada: Reno, Nevada, Geological Society of Nevada, Symposium 2000 Field Trip Guidebook no. 2, p. 1-132.

Gilbert, C.M., and Reynolds, M.W., 1973, Character and chronology of basin development, western margin of the Basin and Range Province: Geological Society of America Bulletin, v. 84, p. 2489-2510, doi: 10.1130/00167606(1973)84<2489:CACOBD>2.0.CO;2.

Harrison, J.A., 1979, Revision of the Camelinae (Artiodactyla, Tylopoda) and description of the new genus Alforjas: University of Kansas: Paleontological Contributions, v. 95 , p. 1-20.

Hulbert, R.C., 1988, Phylogenetic interrelationships and evolution of North American late Neogene Equinae, in Prothero, D.R., and Schoch, R.M., eds., The Evolution of Perissodactyls: Oxford Monographs on Geology and Geophysics 15, p. 178-196.

Hulbert, R.C., and MacFadden, B.J., 1991, Morphological transformation and cladogenesis at the base of the adaptive radiation of Miocene hypsodont horses: American Museum Novitates, no. 3000, p. 1-61.

Hunt, R.M., Jr., 1998, Ursidae, in Janis, C.M., Jacobs, L.L., and Scott, K.M. eds., Evolution of Tertiary Mammals of North America: Cambridge, Cambridge University Press, p. 174-195.

Kelly, T.S., 1994, Two Pliocene (Blancan) vertebrate faunas from Douglas County, Nevada: PaleoBios, v. 16, p. 1-23.

Kelly, T.S., 1997, Additional late Cenozoic (latest Hemphillian to earliest Irvingtonian) mammals from Douglas County, Nevada: PaleoBios, v. 18, p. 1-31

Kelly, T.S., 1998a, New Miocene mammalian faunas from west central Nevada: Journal of Paleontology, v. 72, p. 137-149.

Kelly, T.S., 1998b, New middle Miocene equid crania from California and their implications for the phylogeny of the Equini: Natural History Museum of Los Angeles County: Contributions in Science, no. 473, p. 1-44.

Kelly, T.S., 2000, A new Hemphillian (late Miocene) mammalian fauna from Hoye Canyon, west central Nevada: Natural History Museum of Los Angeles County: Contributions in Science, no. 481, p. 1-21.

King, C., 1878, The Comstock lode, in Hague, J.D., ed., Mining Industry, U.S Geological Exploration of the $40^{\text {th }}$ Parallel: Washington, D.C., U.S. Geological Survey, p. 10-91.

Korth, W.W., 1999, Hesperogaulus, a new genus of mylagaulid rodent (Mammalia) from the Miocene (Barstovian to Hemphillian) of the Great Basin: Journal of Paleontology, v. 73, p. 945-951.

Lambert, W.D., and Shoshani, J., 1998, Proboscidea, in Janis, C.M., et al., eds., Evolution of Tertiary Mammals of North America: Cambridge, Cambridge University Press, p. 606-621.

Macdonald, J.R., 1959, The middle Pliocene mammalian fauna from Smiths Valley, Nevada: Journal of Paleontology, v. 33, p. 872-887.

Macdonald, J.R., and Pelletier, W.J., 1958, The Pliocene mammalian faunas of Nevada, U.S.A.: Session 20: Paleontology, Taxonomy, and Evolution, Section VII: International Geologic Congress, p. 365-388.

MacFadden, B.J., 1984, Systematics and phylogeny of Hipparion, Neohipparion, Nannippus, and Cormohipparion (Mammalia, Equidae) from the Miocene and Pliocene of the New World: Bulletin of the American Museum of Natural History, v. 179, 196 p.

MacFadden, B.J., 1992, Fossil Horses: Systematics, Paleobiology, and Evolution of the Family Equidae: New York, Cambridge University Press, p. $x i i+369$

Merriam, J.C., 1918, New Mammalia from the Idaho Formation: University of California Publications: Bulletin of the Department of Geology, v. 10, p. 523-530.

Perkins, M.E., Brown, F.H., Nash, F.H., McIntosh, W.P., and Williams, S.K., 1998 , Sequence, age, and source of silicic fallout tuffs in middle to late Miocene basins of the northern Basin and Range Province: Geological
Society of America Bulletin, v. 110, p. 344-360, doi: 10.1130/0016-7606 (1998) 110<0344:SAASOS>2.3.CO;2

Prothero, D.R., and Tedford, R.H., 2000, Magnetic stratigraphy of the type Montediablan stage (late Clarendonian, late Miocene), Black Hawk Ranch, Contra Costa County, California: Implication for Clarendonian correlations: PaleoBios, v. 20, p. 1-37.

Repenning, C.A., 1987, Biochronology of the microtine rodents of the United States, in Woodburne, M.O., ed., Cenozoic Mammals of North America Geochronology and Biostratigraphy: Berkeley, University of California Press, p. 236-368.

Repenning, C.A., Weasma, T.R., and Scott, G.R., 1995, The early Pleistocene (latest Blancan-earliest Irvingtonian) Froman Ferry Fauna and history of the Glenns Ferry Formation, southwestern Idaho: U.S. Geological Survey Bulletin 2105, p. 1-86.

Richey, K.A., 1948, Lower Pliocene horses from Black Hawk Ranch, Mount Diablo, California: University of California Publications in Geological Sciences, v. 28, p. 1-44.

Savage, D.E., 1955, Nonmarine lower Pliocene sediments in California: University of California Publications in Geological Sciences, v. 31, p. 1-26.

Schorn, H.E., Bell, C.J., Starratt, S.W., and Wheeler, D.T., 1994, A computerassisted annotated bibliography and preliminary survey of Nevada paleobotany: U.S. Geological Survey Open-File Report 94-441A, 180 p.

Shotwell, J.A., 1955, Review of the Pliocene beaver Dipoides: Journal of Paleontology, v. 29 , p. $129-144$

Shotwell, J.A., 1970, Pliocene mammals of south-east Oregon and adjacent Idaho: Bulletin of the Museum of Natural History, University of Oregon, no. 17 , p. $1-103$

Stirton, R.A., 1939, Cenozoic mammal remains from the San Francisco Bay region: University of California Publications: Bulletin of the Department of Geological Sciences, v. 24, p. 339-410.

Stirton, R.A. 1940, The Nevada Miocene and Pliocene mammalian faunas as faunal units: Proceedings of the VI Pacific Science Congress, no. 2, p. 627-640.

Streck, M.J., and Grunder, A.L., 1995, Crystallization and welding variations in a widespread ignimbrite sheet; the Rattlesnake Tuff, eastern Oregon USA: Bulletin of Volcanology, v. 57, p. 151-169.

Swisher, C.C., III, $1992,{ }^{40} \mathrm{Ar} /{ }^{39} \mathrm{Ar}$ dating and its application to the calibration of the North American land mammal ages [Ph.D. thesis]: Berkeley, University of California, $239 \mathrm{p}$.

Tedford, T.H., Albright, L.B., III, Barnosky, A.D., Ferrusquia-Villafranca, I., Hunt, R.M., Jr., Storer, J.E., Swisher, C.C., III, Voorhies, M.R., Webb, S.D., and Whistler, D.P., 2004, Mammalian biochronology of the Arikareean through Hemphillian interval (late Oligocene through early Pliocene epochs), in Woodburne, M.O., ed., Late Cretaceous and Cenozoic Mammals of North America: New York, Columbia University Press, p. 169-231.

Trexler, J.H., Jr., Cashman, P.H., Henry, C.D., Muntean, T., Schwartz, K., TenBrink, A., Faulds, J.E., Perkins, M., and Kelly, T., 2000, Neogene basins in western Nevada document the tectonic history of the Sierra NevadaBasin and Range transition zone for the last $12 \mathrm{Ma}$, in Lageson, D.R., et al., eds., Great Basin and Sierra Nevada: Boulder, Colorado: Geological Society of America Field Guide 2, p. 97-116.

Walsh, S.L., 1998, Fossil datum and paleobiological event terms, paleontostratigraphy, chronostratigraphy, and the definition of land mammal "age" boundaries: Journal of Vertebrate Paleontology, v. 18, p. 150-179.

Whistler, D.P., and Burbank, D.W., 1992, Miocene biostratigraphy and biochronology of the Dove Spring Formation, Mojave Desert, California, and characterization of the Clarendonian mammal age (late Miocene) in California: Geological Society of America Bulletin, v. 104, p. 644-658, doi: 10.1130/0016-7606(1992) 104<0644:MBABOT>2.3.CO;2.

Wilson, E.L., and Prothero, D.R., 1997, Magnetic stratigraphy and tectonic rotation of the middle-upper Miocene "Santa Margarita" and Chanac Formations, north-central Transverse Ranges, California, in Girty, G.H., Hanson, R.E., and Cooper, J.D., eds., Geology of the Western Cordillera: Perspectives from Undergraduate Research: Pacific Section, Society of Economic Paleontologists and Mineralogists Special Publication 82, p. 35-48.

Woodburne, M.O., 1987, Cenozoic Mammals of North America, Geochronology and Biostratigraphy: Berkeley, University of California Press, p. xv +336

Woodburne, M.O., 2004, Late Cretaceous and Cenozoic Mammals of North America, Biostratigraphy and Geochronology: New York, Columbia University Press, p. xv +391 .

MANUSCRIPT ACCEPTED By THE SOCIETy 21 JuLy 2008 